\title{
Analysis on Cultivation and Construction of Talent Team in Library and Information Science Specialty
}

\author{
Kaijun Yu, Ruiyi Gong \\ Shanghai University of Medicine \& Health Sciences, Shanghai, China \\ Email: healthcare@163.com
}

Received 30 March 2016; accepted 24 April 2016; published 27 April 2016

Copyright (C) 2016 by authors and Scientific Research Publishing Inc.

This work is licensed under the Creative Commons Attribution International License (CC BY). http://creativecommons.org/licenses/by/4.0/

cC) (7) Open Access

\begin{abstract}
Cultivation and construction of professional talent team in library and information science have important practical significance on promoting the rapid development of professional information intelligence, improving the service level of information intelligence and meeting people's requirements for information intelligence. The article firstly analyzes problems existed in cultivation of talent team in library and information science specialty, and then puts forward methods to solve problems with pertinence, providing references for cultivation and construction of talent team in library and information science specialty.
\end{abstract}

\section{Keywords}

Library and Information Science, Professional Talent Team, Cultivation, Construction, Problems

\section{Introduction}

In recent years, with the development of communication technology and information technology, the integral level of society informatization in our country improves rapidly. The requirements of the broad masses of the people for information intelligence become diversified, personalized, efficient and professional. Under this circumstance, it has become an important task for library and information organizations to provide all-around information intelligence service for the masses [1]. Although in recent years, the library and information science of our country have developed rapidly and delivered a large number of talents for our society, it is still difficult to meet the demand of society. Therefore, cultivation and construction of talent team in library and information science specialty have very important practical significance on promoting the rapid development of professional information intelligence, improving the service level of information intelligence and meeting people's require- 
ments for information intelligence.

\section{Problems Existed in Cultivation of Talent Team in Library and Information Science Specialty at the Present Stage}

\subsection{Education of Library and Information Science Specialty Restricts the Cultivation of Professional Talent Team}

At present, the education of library and information specialty in our country is relatively backward and seriously restricts the cultivation of talent team in library and information science specialty in our country. Firstly, the teaching materials of library and information science in our country update slowly. The course contents are universally outdated. At present, the library and information science specialty in our country faces the challenges of globalization, knowledge and network. The levels of knowledge and technology develop increasingly. However, the teaching materials of quite a number of library and information science in colleges generally update slowly. Some colleges even still follow teaching materials of the last century. Some library and information specialties even do not have teaching materials. They can only use the way that the teacher teach and students take notes; secondly, problems exist in curriculum provision of library and information science. At present, the curriculum provision of library and information science specialty in our country is generally large and comprehensive. This kind of curriculum provision not only lacks characteristics, but also is relatively blind, almost containing all courses involved in library and information science. Even though it expands students' scope of knowledge, students needs to make greater efforts in learning. Besides, most students only learn the surface knowledge. They have not time or it is difficult for them to learn knowledge at a deeper level. It is harder to apply it to practice [2]. Thirdly, the teaching methods are relatively backward. At present, although the reform in education that centers on students has been in full swing, quite a number of colleges still adopt traditional teaching methods. In class, teachers are self-centered and give a lesson according to their knowledge structure, practice level and hobbies and interests, without giving consideration to whether it can arouse students' enthusiasm for learning. In teaching process, many teachers pay more attention to theory and attach less importance to practice. It is only limited to computer operation when it involves practical operation. Although students cultivated in this way have relatively high theoretical level, they have poor operational ability and cannot meet the needs of development of times. Fourthly, teachers are seriously inadequate. Although communication technology and information technology develop rapidly, teachers in library and information science in colleges cannot realize rapid replacement. It leads to the fact that teachers' level and structure of knowledge seriously lag behind the development of communication and information technology. Moreover, quite a number of teachers have backward teaching thoughts. They cannot make in-depth learning and research on teaching of library and information science specialty in the era of rapid development of communication and information technology. What's more, it is even difficult for them to meet the requirements of course reform. Some teachers even refuse to introduce course reform in class and still adopt backward and traditional teaching methods to teach. Besides, some colleges still have the phenomenon that teachers' specialties are not geared to the needs of the job and one teacher teach several courses [3].

\subsection{Market Positioning of Library and Information Science Specialty Restricts the Cultivation of Professional Talent Team}

With continuous development and improvement of socialist market economy in our country, the positioning of previous library and information science that establishes in the era of planned economy has been far from meeting the needs of market development. Under this circumstance, it becomes the problem that must be solved at present that library and information science specialty uses what kind of appearance and image to differ from other specialties and then meets requirements of the market. Conceptually, the library and information science specialty includes contents such as library science, information science and intelligence science. Besides, the specialty of library and specialty of information science exist in the identity of disciplines at the same level [4]. However, with the development of great intelligence concept, the research fields and objects of library and information science change continuously, and the research contents also gradually go deep into different fields of information science, and then expand the research scope of library and information science. Because the market positioning is not clear, in the process of development, the library and information science has gradually ap- 
peared the defects that it is divorced from reality and involves excessive large scope. It results in that many colleges go wrong in setup of library and information science. They set it as specialty of library, specialty of intelligence, information management specialty, and public management specialty or education management major. This kind of situation teems, which fundamentally reflects problems existed in positioning of library and information specialty in our country. Students cultivated under this kind of condition cannot be called as talents. Their knowledge structure and ability level are difficult to meet the requirements of market development [5].

\subsection{Hierarchical Structure of Library and Information Science Specialty Restricts the Cultivation of Professional Talent Team}

With continuous improvement of level of informatization, people have increasingly strong demands for knowledge and information. Library and information can provide a variety of information for us through many ways to meet the demands of people for knowledge and information. In order to meet this need, library and information science specialty must cultivate a large number of talents of higher level to serve the society. But it is regrettable that the hierarchical structure of library and information science specialty in our country cannot meet the requirements of social development. It is difficult to cultivate large numbers of talents of higher level. Looking from the structure of talent cultivation, the higher education in our country mainly tends to the cultivation of undergraduates. The cultivation of postgraduates is in the second place. Compared with knowledge structure and ability level of undergraduates, postgraduates are obviously even better. This kind of professional hierarchical structure that centers on cultivating undergraduates is difficult to meet the needs of society for talents of higher level as well as improve comprehensive quality of library and information science specialty of our country. Besides, the education level of library and information science in colleges of our country remains to be improved. It not only needs to formulate research projects at undergraduate level, level of postgraduate and level of doctor student and improve the scientific research levels of undergraduate, postgraduate and doctor students. Meanwhile, it shall formulate related training plans to train talents in school and at their posts through many ways and continuously improving the knowledge levels of talents of library and information science.

\section{Cultivation and Construction of Talent Team in Library and Information Science Specialty}

\subsection{Comprehensively Improve the Educational Level of Library and Information Science Specialty}

(1) Optimize curriculum provision

Curriculums are basis for cultivation and construction of talent team of library and information science specialty. To cultivate and construct talent team of library and information science specialty, first of all, it is necessary to center on training objectives to optimize curriculum provision. In the process of curriculum optimization, pragmatic principle must be insisted on. The main purpose of talent team of library and information science specialty is to provide service for the masses as well as promote the development of library and information science specialty. During this process, talents of library and information science specialty shall not only construct and manage knowledge value chain of relevant structure, but also carry out related activities by entering the market, which have relatively strong practicality. Adhering to the principle of practicality can not only make students learn related management theory, but also improve their abilities to analyze specific issues concretely and solve practical problems through relevant theories. Secondly, in the process of optimization of curriculum, it is also necessary to insist on the principles of inheritance and innovation. The development of anything bases on the original things. The optimization of curriculum in library and information science specialty is also the same. In the process of optimization, they shall reasonably retain part of the existing curriculum and compress and merge repetitive curriculums. At the same time, they should absorb foreign advanced theories and knowledge carefully, do relevant research on new problems appeared in the process of market development and create new curriculums suitable for the development of market situation. In addition, in the process of curriculum optimization, it is also essential to ensure the characteristics of curriculum and avoid being assimilated by other disciplines such as computer science and economics and make efforts to create modern curriculum system that has the characteristics of this specialty.

(2) Construct modular curriculum 
Constructing modular curriculum according to students' level of knowledge and development direction is an important condition to comprehensively improve the educational level of library and information science specialty. In the process of constructing modular curriculum, it is necessary to divide curriculums into multiple modules according to relevant standards. In the modules, they should arrange traditional theories, related theories that adapt to market development and technology progress and contents of practical operation. In order to meet the requirements of different students for learning, the construction of module curriculum should set about from the following two aspects. 1) Construction of compulsory curriculum module. The module of compulsory courses is the basis of students' learning. The contents need to include curriculum module of basic theory, curriculum module of basic knowledge and curriculum module of professional skill. Curriculum module of basic theory includes basic theories such as introduction to information science of library science, theory of literature information retrieval, library management. Curriculum module of basic knowledge mainly includes curriculum of basic knowledge involved in library and information science, including basic knowledge such as computer knowledge, scientific methodology, foreign language, advanced mathematics, introduction to management. Curriculum module of professional skill mainly includes professional and technical knowledge such as manual information retrieval, computer network information retrieval, information system design, information system analysis, management information system, database management and data analysis. 2) Construction of elective curriculum module. Elective curriculum module is established according to requirements of students' specialty development. Its content mainly includes relevant modules such as knowledge management, competitive intelligence, digital library, market information and service, publication and dissemination, policy and regulation, business management. The module of knowledge management mainly includes contents of knowledge audit, knowledge organization, and knowledge sharing management, management of knowledge innovation, knowledge representation and modeling. The module of competitive intelligence mainly includes information forecast and analysis, core competence analysis, competitive advantage, analysis of competitors and environment, competitive intelligence game. The module of digital library mainly includes digital reference service, Ontology, information filtering, personalized information, metadata and artificial intelligence. The module of market information and service mainly includes information economics, research on information market, information service and marketing, information integration service. The module of publication and dissemination mainly includes theory of communication science, publication and marketing, visual communication. The module of policy and regulation mainly includes information policy, intellectual property law, information security policies, and commercial secret protection. The module of business management mainly includes enterprise resource planning, electronic commerce, enterprise informatization, strategic management and project management [6].

(3) Define three-dimensional purpose of curriculum

Under the traditional teaching model that centers on class, books and teachers, teachers simply impart knowledge into students without considering whether students are willing to learn. It is difficult to fully arouse students' subjective initiative and it even causes students' disgust, reduces their creative ability, especially goes against the development of their personality and expertise and cannot cultivate interdisciplinary talents. To improve teaching level and achieve the purpose to cultivate and construct talent team of library and information science, it is necessary to define the three-dimensional purpose of curriculum and construct teaching model that centers on students. The three-dimensional purpose of curriculum refers to knowledge and skills, process and method, emotional attitudes and values. Firstly, define knowledge and skill objectives, make students of library and information science specialty acquire basic knowledge and basic skills through a variety of ways. Secondly, define objectives of process and method, cannot simply impart knowledge and train skills. It should not be confined to class, the narrow and simple communication space, but expand from classroom to outside class, from library and information science to other discipline, from school to society, continuously improving students' levels of library and information science. Thirdly, define objectives of emotional attitudes and values. In the process of learning, emotional attitudes have very important effects and even determine the final result of learning. Therefore, in the process of teaching, teachers must pay attention to cultivate emotional attitudes and values of secondary vocational school students, guide students to participate in course discussion and continuously improve students' enthusiasm to participate in class through discussion between teachers and students as well as between students. In the process of teaching, teachers should also make efforts to change idea to place students in the center of class from many aspects, and then continuously improve their learning consciousness and enthusiasm for learning. 


\subsection{Give Reasonable Market Positioning for Library and Information Science Specialty}

The market needs various types of professional talents. In the process of selecting talents, different organizations have different directions to select talents. But most organizations tend to select interdisciplinary talents and innovative talents. In order to adapt to talent selection of enterprises, library and information science specialty must give reasonable market positioning, namely, position the market of library and information science specialty in cultivating interdisciplinary and innovative talents. In essence, no matter cultivating innovative talents or interdisciplinary talents, the purpose is to cultivate practical talents suitable for social development. Only through cultivating students' creative spirit can they fully arouse knowledge and skills of their own when they meet new situation and new problems, explore methods to respond to new situation and solve new problems, and then continuously explore new knowledge, promote the development of library and information science. Except for the reasonable market positioning of schools for library and information science, students of library and information science specialty should also make reasonable market positioning, strengthen the learning of basic and related knowledge for library and information science, and make efforts to grow into interdisciplinary and innovative talents with high knowledge level and strong operational capacity [7].

\subsection{Improve Hierarchical Structure of Library and Information Science Specialty}

With the development of society, it has increasing high demands for professional talents of high academic qualifications and high levels. Under this circumstance, institutions of higher learning must reasonably improve hierarchical structure of library and information science specialty, change traditional professional hierarchical structure that centers on cultivating undergraduates and attach less importance to postgraduates, and gradually establish professional hierarchical structure with comprehensive development of multiple levels. To meet requirements of different organizations for talents, schools shall also reinforce investigation and survey, reasonably analyze requirements of market and reasonably allocate the proportion of undergraduates, postgraduates and doctor students. Meanwhile, institutions of higher learning shall also formulate corresponding training objectives according to different professional hierarchical structures and cultivate talents of related professional levels that suit different organizations on the basis of meeting requirements of talent cultivation. For example, key universities allocate more quotas for postgraduates of library and information science specialty to meet the requirements of research-type library, professional library and large-scale library for research-based talents of high levels. Common undergraduate course colleges allocate more quotas for undergraduates of library and information science specialty to meet the requirements of small and medium size of information organizations and libraries for medium interdisciplinary talents [8].

\section{Conclusion}

In conclusion, with further development of socialist market economy, the market has increasingly high demands for talents. Under this circumstance, institutions of higher learning can meet talent demands of different organizations and promote the development of library and information science only through carefully analyzing the market, reasonably cultivating and constructing talent team in library and information science specialty and continuously improving the comprehensive competitive ability of talents in library and information science specialty.

\section{References}

[1] Shen, G.Z. and Zhou, Z.Y. (2011) Thinking on "Double Degree” Education of Master of Library and Information Studies. Journal of Library Science in China, No. 1, 24-31.

[2] Li, Y.L., Yan, H. and Ge, P. (2011) Create MBA in LIS Field: Thinking on Education of MLIS Degree. Library and Information Service, 55, 24-27.

[3] Jiang, Y.F. and Sun, M. (2013) Moving Towards Diversification: Research on Construction of Cultivating Diversified System for Graduate Students of Library Science in Our Country. Library Construction, No. 2, 1-5, 12.

[4] Hu, L.L. (2015) Comparison of Characteristics of Postgraduates Cultivating Model Between Academic Degree and Professional Degree. Academic Degrees and Graduate Education, 6, 22-26.

[5] Bai, C.J., Du, Y.F. and Wang, H. (2010) Looking Innovative and Practical Cultivating Trend of Postgraduates of MLIS from Research Direction. Library and Information Service, No. 7, 71-74.

[6] Wang, X.Z. (2012) Research Summary on Demands and Innovation Ability Training for Postgraduate Talents in Li- 
brary and Information and Archives Management. Archives Science Study, No. 2, 83-88.

[7] Wang, X.Z. (2014) Analysis on Influence Factor and Countermeasures of Cultivation for Postgraduate Talents in Library and Information and Archives Management. Archives Science Study, No. 3, 75-80.

[8] Li, J. (2011) Current Situation and New Tendency of Research on Discipline Construction of Library and Information and Archives Management in Our Country-Statistic Analysis on Application Materials of Master Degree Station of First-Level Discipline in 2010. Library and Information Service, 55, 39-42. 